\title{
Characteristics of Thai Native Beef Slaughtered by Traditional Halal Method
}

\author{
Ari WIBOWO ${ }^{1,2}$, Worawan PANPIPAT ${ }^{1}$, \\ Siriporn Riebroy $\mathrm{KIM}^{3}$ and Manat CHAIJAN ${ }^{1, *}$
}

${ }^{1}$ Food Technology and Innovation Research Center of Excellence, Division of Agro-Industry, School of Agricultural Technology, Walailak University, Nakhon Si Thammarat 80161, Thailand

${ }^{2}$ Departement of Animal Science, Agricultural Faculty, Mulawarman University,

East Kalimantan Timur 75123, Indonesia

${ }^{3}$ Food and Nutrition Program, Faculty of Agriculture, Kasetsart University, Bangkok 10900, Thailand

('Corresponding author's e-mail: cmanat@wu.ac.th)

Received: 27 November 2017, Revised: 29 April 2018, Accepted: 8 May 2018

\begin{abstract}
Chemical compositions and physicochemical properties relating to the eating quality of 3 beef cuts, Semitendinosus (SET), Longissimus dorsi (LNG), and Vastus lateralis (VAL), of Thai native beef cattle slaughtered by the traditional Halal method (without stunning) were reported. Chemical compositions varied depending on muscle type. VAL had the highest zinc content $(30.99 \mathrm{mg} / \mathrm{kg}$ ), whereas the highest iron content was found in LNG $(15.93 \mathrm{mg} / \mathrm{kg})$. VAL showed higher myoglobin content $(2.67 \mathrm{mg} / \mathrm{g})$ than LNG $(2.54 \mathrm{mg} / \mathrm{g})$ and SET $(1.41 \mathrm{mg} / \mathrm{g})$, respectively $(P<0.05)$. All cuts were categorized as dark cutting beef, in which deoxymyoglobin was the most predominant $(55.67-59.89 \%)$, and where $\mathrm{pH}_{(3 \mathrm{~h})}$ was quite high $(6.26-6.93)$. VAL had the highest $\mathrm{pH}_{(24 \mathrm{~h})}$ of $6.4(P<0.05)$ compared to SET and LNG $\left(\mathrm{pH}_{(24 \mathrm{~h})}=\right.$ 5.8). VAL tended to show the lowest expressible drip, with the lowest cooking loss, followed by SET and LNG, respectively. LNG had lower hardness than SET and VAL $(P<0.05)$. Therefore, differences of compositions and physicochemical properties of Thai native beef slaughtered by traditional Halal method were associated with muscle type.
\end{abstract}

Keywords: Traditional Halal slaughter, Thai native beef, physicochemical properties, chemical composition

\section{Introduction}

Over the decades, producers and consumers have been concerned about the way of handling, slaughtering, and processing beef cattle for providing meat as a Halal product [1]. Consumers are also focused on the quality and safety of meat produced by religious slaughter. Thus, providing meat based on religious slaughter and the nutritional content information from beef cuts are important [2]. The essence of nutritive content in red meat can be affected by several factors, such as the process of animal handling during production period, and the slaughtering method, which can affect the quality of the carcass and meat post-mortem. Pre-slaughter handling and the method of slaughter being used for slaughtering animals are the main factors determining the chemical composition and eating quality of beef. Additionally, the chemical composition and physicochemical properties of beef cuts are different depending on the muscle position, function, and activity from the anatomical and physiological points of view [3]. It has been reported that the chemical composition, physicochemical properties, and flavor characteristics of beef differ by the type of cut [4] Anatomical types of retail beef cuts generally have different nutritional compositions and physicochemical properties which contribute to the eating quality 
http://wjst.wu.ac.th

of beef [2,4]. For instance, loin, tenderloin, and rib cuts have a higher fat content compared to semitendinosus and knuckle, due to the type of action and position of each cut $[3,4]$. Furthermore, different contents of heme pigments, particularly myoglobin, can be found among muscle types, leading to variations in the color of retail cuts [3]. However, information regarding the chemical composition and physicochemical properties relating to eating quality of Thai native beef cuts prepared by traditional Halal method is scarce. Therefore, the objective of this study was to evaluate some chemical compositions and physicochemical properties of 3 retail cuts derived from different muscle locations, Semitendinosus (SET), Longissimus dorsi (LNG), and Vastus lateralis (knuckle; VAL), of Thai native beef slaughtered by the traditional Halal method (without stunning) from local Halal slaughter houses in Thasala, Nakhon Si Thammarat, Southern Thailand.

\section{Materials and methods}

Traditional Halal slaughter and beef samples

Meat samples were collected from 3 female Thai native beef cattle (Bos indicus), 36 months old, with initial body weights of $350 \pm 5.0 \mathrm{~kg}$. Beef cattle were slaughtered and fabricated at traditional Halal slaughterhouses in Thasala, Nakhon Si Thammarat, Southern Thailand, in April, 2017. The traditional Halal slaughter houses operated from $2.00-6.00 \mathrm{am}$. The beef samples consisted of 3 parts of retail cuts, SET, LNG, and VAL (Figure 1). Samples were packed in plastic bags, covered with ice, using an ice: meat ratio of $2: 1(\mathrm{w} / \mathrm{w})$ in polystyrene boxes, and transported to the Department of Agro-Industry, Walailak University, within $45 \mathrm{~min}$. The total time from slaughter to analysis was $3 \mathrm{~h}$. At $3 \mathrm{~h}$ postmortem, physicochemical analyses, which were $\mathrm{pH}$, expressible drip, cooking loss, hardness, and color, were performed. The other lots of samples were placed in chilled storage for $21 \mathrm{~h}$ at $5{ }^{\circ} \mathrm{C}$ to achieve a total of $24 \mathrm{~h}$ post-mortem, and the physicochemical parameters were analyzed again. The chemical compositions, which were moisture, protein, fat, ash, zinc, iron, myoglobin, and myoglobin redox, were determined at $24 \mathrm{~h}$ post-mortem. Samples were kept on ice during preparation and analysis.

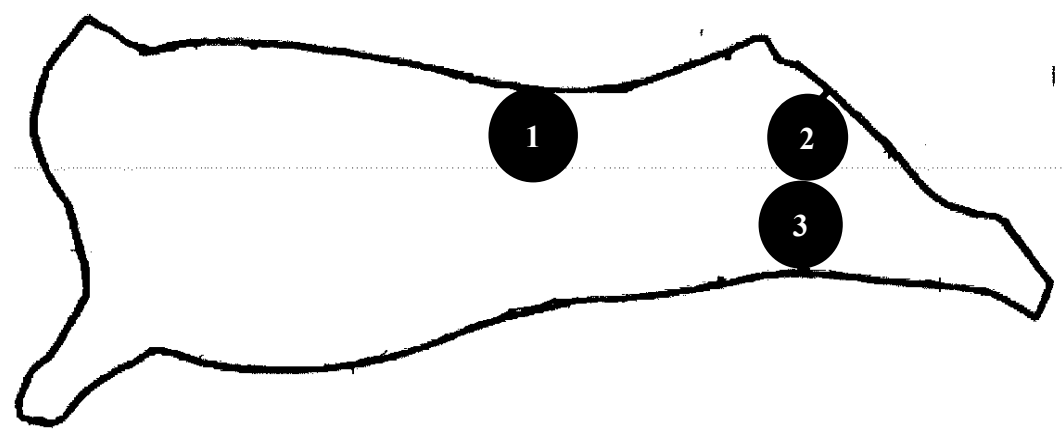

Figure 1 Anatomical location of 3 beef cuts, Longissimus dorsi (1), Semitendinosus (2) and Vastus lateralis (3).

\section{Proximate composition and mineral determinations}

Moisture, protein, fat, and ash contents of 3 beef cuts were determined according to AOAC [5]. Zinc and iron contents were determined by the inductively coupled plasma-optical emission spectrometer (ICP-OES) (Perkin Elmer, Model 4300 DV, USA) [6].

Total myoglobin content and proportion of myoglobin forms

Myoglobin was extracted from beef using cold $0.04 \mathrm{M}$ phosphate buffer at $\mathrm{pH} 6.8$ [7] and converted to the deoxy-form by adding an excess of a reducing agent, sodium hydrosulfite. The absorbance was 
http://wjst.wu.ac.th

recorded at $433 \mathrm{~nm}$. The myoglobin content was calculated and expressed as $\mathrm{mg} / \mathrm{g}$. Measurement of myoglobin redox was conducted by the method of Faustman and Philips [8]. The proportions of the 3 myoglobin forms (deoxymyoglobin, oxymyoglobin, and metmyoglobin) were calculated using a modified Krzywicki's equation [9].

\section{Determination of $\mathbf{p H}$}

Samples were homogenized using an IKA Labortechnik homogenizer (Selangor, Malaysia) with 10 volumes of deionized water (w/v), and the $\mathrm{pH}$ was measured using a calibrated $\mathrm{pH}$ meter (Cyberscan 500, Singapore).

\section{Determination of expressible moisture and cooking loss}

Expressible moisture of beef was measured according to the method of $\mathrm{Ng}$ [10] and expressed as percentage of sample weight. Analysis of cooking loss was performed as described by Purslow et al. [11].

\section{Hardness}

Texture analysis of meat was performed using a TA-XT2 texture analyzer (Stable Micro Systems, Godalming, Surrey, U.K.) equipped with a spherical plunger (diameter $5 \mathrm{~mm}$; depression speed 60 $\mathrm{mm} / \mathrm{min}$ ) [12].

\section{Color measurement}

Surface color analysis was performed by using a portable Hunterlab Miniscan/EX instrument $\left(10^{\circ}\right.$ standard observers, illuminant D65, Hunter Assoc. Laboratory; VA, USA). The tristimulus L* (lightness), $\mathrm{a}^{*}$ (redness/greenness), and b* (yellowness/blueness) values were reported.

\section{Statistical analysis}

A completely randomized design was used in this study and the entire experiment was replicated 3 times. Data were subjected to analysis of variance (ANOVA). Comparison of means was carried out by Duncan's multiple-range test to identify significant differences $(P<0.05)$ among treatments [13]. In the case of paired comparison, a paired-t test was used. Statistical analysis was performed using the Statistical Package for Social Science (SPSS 10.0 for windows, SPSS Inc., Chicago, IL, U.S.A.).

\section{Results and discussion}

\section{Traditional Halal slaughter process}

Recently, there has been debate about Halal slaughter, due to non-stunning before the slaughtering process, among welfare supporters and researchers. Through this experiment, we tried to define and describe the effect of the Halal traditional slaughter method (non-stunning) on the quality of 3 beef cuts from different anatomical positions of Thai native cattle. The pre-slaughter practice of the traditional slaughterhouse in Thasala district was poor in terms of animal handling technique (Figure 2). Based on the observation, beef cattle underwent stress prior to slaughter because of poor knowledge about animal attitudes and behaviors. The stockman did not fully understand how to handle animals gently and properly (Figures 2A - 2C). During overthrow (Figures 2D - 2F), 3 beef cuts, SET, LNG, and VAL, underwent hard physical contact with the floor at the slaughter area. However, due to the muscle location, VAL and SET had high risk for wound and bruise formation when compared to LNG. Both stress and impact force applied to the animal may lead to direct decline in the quality of meat (Figures 2A - 2F). Farouk et al. [14] highlighted that the manner in which livestock are mustered, yarded, handled, transported, restrained, slaughtered, and exsanguinated can affect their welfare and the final meat quality. 

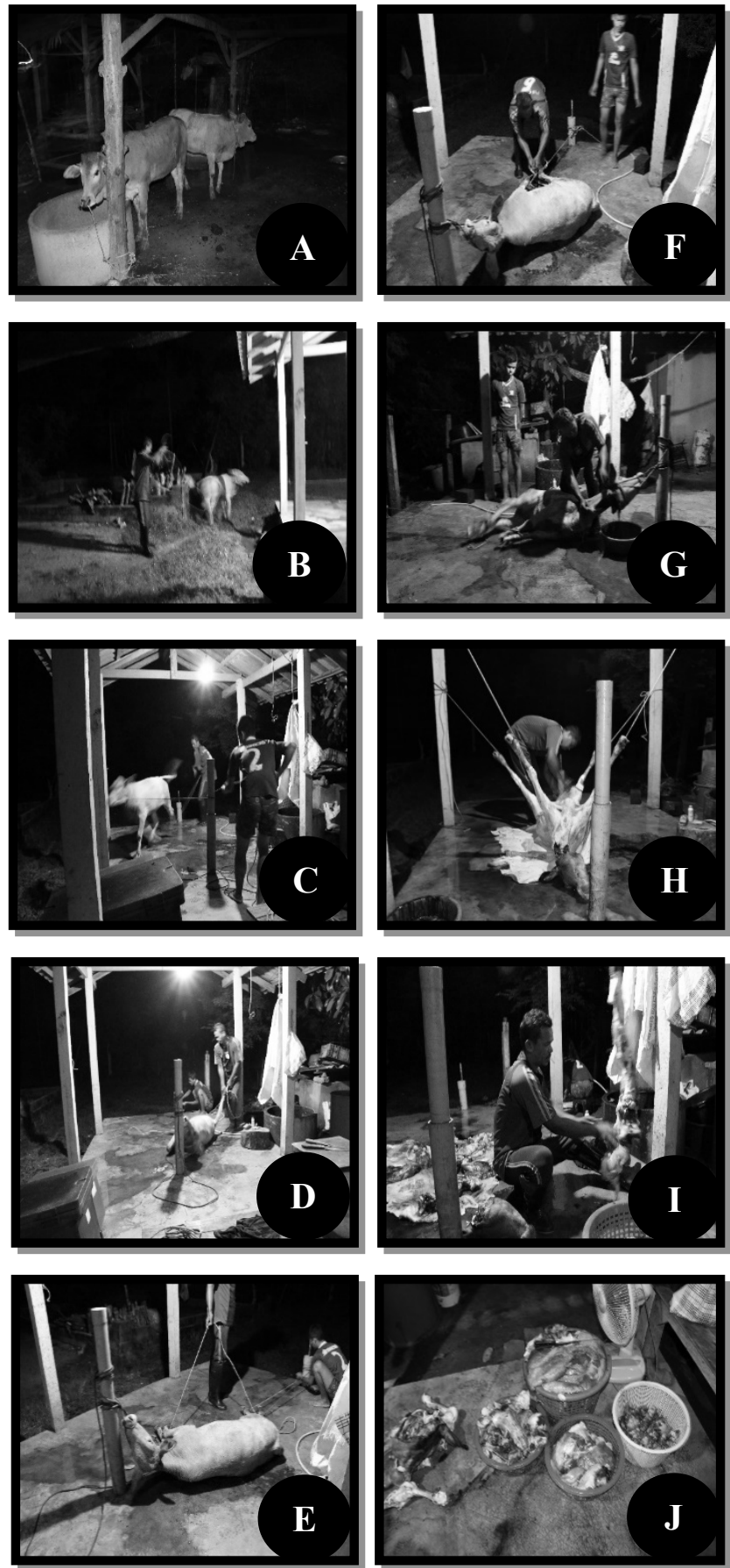

Figure 2 Traditional Halal practices in slaughtering and meat handling in Thasala, Nakhon $\mathrm{Si}$ Thammarat, Southern Thailand. Cattle handling from lairage to slaughter area (A, B and C), overthrow method using ropes prior to slaughter (D, E, F) and slaughter technique and meat cutting process $(\mathrm{G}, \mathrm{H}, \mathrm{I}$, and $\mathrm{J}$ ). 
http://wjst.wu.ac.th

Although the slaughtering process could be achieved optimally, the tools and equipment used were not suitable from the animal welfare viewpoint. Animals can react violently if a substandard knife is used during slaughter without stunning. From the observation, the slaughter knife used in the traditional slaughterhouse in Thasala seemed not to follow the standard for slaughtering beef cattle, leading to the flinching of beef cattle during slaughter and post incision procedure (Figure 2G). Obviously, the type and size of knife were not appropriate for slaughtering beef, where that knife was too short and blunt. To achieve animal welfare standards and reduce the risk of repetitive injury to the worker, the knife must be maintained and sharpened regularly before and after use [15]. Blunt knives are unacceptable in slaughtering practice without stunning because it results in more suffering and is more painful for the animal during bleeding after the slaughtering process [14]. Therefore, the type and size of knife seemed to play important roles in reducing pain during slaughter with the traditional Halal method.

After slaughtering with the traditional Halal method, the carcasses were directly fabricated into retail cuts. Figures 2A - 2J show the steps from skinning to cutting meat into retail cuts. The handling of carcasses at traditional Halal slaughterhouses in Thasala has been done on the floor, which could be contaminated by microorganisms, risking the deterioration of raw meat and further products. After skinning and eviscerating, 2 hind quarters of beef were separated from the body and then hung for cutting SET and VAL using a boning knife; LNG was fabricated from the back bone of beef cattle, since the LNG position runs along the top of the spine from hip to shoulder.

\section{Proximate composition}

The proximate compositions of 3 beef retail cuts slaughtered by the traditional Halal method are presented in Table 1. In all cuts, moisture was the most abundant constituent, accounting for 76.56 $77.51 \%$, followed by protein $(21.03-21.54 \%)$, ash $(1.18-1.28 \%)$, and fat $(0.46-0.65 \%)$, respectively. SET had lower moisture content $(76.56 \%)$ than LNG $(77.29 \%)$ and VAL $(77.51 \%)(P<0.05)$. Pflanzer and de Felício [16] found 73.80 and $75.20 \%$ moisture in LNG samples from cows over 4 years and cows under 4 years of age, respectively. No significant differences in protein content amongst beef cuts were found $(P>0.05)$. The protein contents in 3 beef cuts in this study were similar with Desimone et al. [2] who found the average protein content in beef cuts was $22-28 \%$.

Table 1 Proximate composition, zinc, iron, myoglobin, and proportion of myoglobin forms (deoxymyoglobin, oxymyoglobin, and metmyoglobin) of 3 beef cuts, Semitendinosus, Longissimus dorsi, and Vastus lateralis, slaughtered by the traditional Halal method.

\begin{tabular}{lccc}
\hline Chemical composition & Semitendinosus & Longissimus dorsi & Vastus lateralis \\
\hline Moisture (\%) & $76.56 \pm 1.01^{\mathrm{a}}$ & $77.29 \pm 0.31^{\mathrm{b}}$ & $77.51 \pm 0.89^{\mathrm{b}}$ \\
Protein (\%) & $21.52 \pm 0.44^{\mathrm{a}}$ & $21.54 \pm 0.85^{\mathrm{a}}$ & $21.03 \pm 0.54^{\mathrm{a}}$ \\
Fat (\%) & $0.65 \pm 0.47^{\mathrm{b}}$ & $0.46 \pm 0.28^{\mathrm{a}}$ & $0.51 \pm 0.30^{\mathrm{a}}$ \\
Ash (\%) & $1.28 \pm 0.17^{\mathrm{b}}$ & $1.18 \pm 0.05^{\mathrm{a}}$ & $1.19 \pm 0.15^{\mathrm{a}}$ \\
Zinc (mg/kg) & $19.54 \pm 0.23^{\mathrm{a}}$ & $32.01 \pm 1.53^{\mathrm{b}}$ & $30.99 \pm 1.05^{\mathrm{b}}$ \\
Iron (mg/kg) & $12.12 \pm 0.82^{\mathrm{a}}$ & $15.93 \pm 0.23^{\mathrm{b}}$ & $12.94 \pm 0.05^{\mathrm{a}}$ \\
Myoglobin (mg/g) & $1.41 \pm 0.55^{\mathrm{a}}$ & $2.54 \pm 0.11^{\mathrm{b}}$ & $2.67 \pm 0.28^{\mathrm{c}}$ \\
Deoxymyoglobin (\%) & $55.67 \pm 0.01^{\mathrm{a}}$ & $59.89 \pm 0.15^{\mathrm{b}}$ & $59.22 \pm 0.70^{\mathrm{b}}$ \\
Oxymyoglobin (\%) & $31.96 \pm 0.05^{\mathrm{b}}$ & $30.51 \pm 0.05^{\mathrm{a}}$ & $30.73 \pm 0.20^{\mathrm{a}}$ \\
Metmyoglobin (\%) & $12.37 \pm 0.00^{\mathrm{c}}$ & $9.60 \pm 0.03^{\mathrm{a}}$ & $10.05 \pm 0.00^{\mathrm{b}}$ \\
\hline
\end{tabular}

Values are given as mean \pm standard deviation from triplicate determinations.

Different letters in the same row indicate significant differences $(P<0.05)$. 
http://wjst.wu.ac.th

Contrarily to moisture, fat content in SET $(0.65 \%)$ was higher than in LNG $(0.46 \%)$ and VAL $(0.51 \%)(P<0.05)$. However, the fat content of 3 beef cuts slaughtered by the traditional Halal method in this study differed from previous reports. For example, Pflanzer and de Felício [16] found $3.30-4.50$ $\%$ fat in LNG samples from cows. Theoretically, the amount of fat in muscle can be influenced by several factors. Nutrition plan and nutrient content in feed have significant effects on fat content in meat. Feeding systems play an important role in beef quality and fat content in particular. Beef cattle grown by grazing systems showed lower fat content compared to grain-fed beef [17]. For native beef cattle production in Southern Thailand, cows are commonly grown on grazing or pasture areas. However, poor knowledge on animal nutrition and feeding management may lead to the malnourishment of animals, which strongly relates to lower fat and marbling content in beef $[16,17]$.

For the total ash content in 3 beef cuts, it was found that SET (1.28\%) had the highest total ash content compared to LNG $(1.18 \%)$ and VAL $(1.19 \%)(P<0.05)$. This finding was similar with previous research, in which the total ash contents in brisket, loin, tenderloin, and 6 other cuts from Hanwoo steer beef (quality grade 1) were found to be in the ranges of $0.7-1.4 \%$ [4].

\section{Zinc and iron}

Zinc and iron contents of 3 beef cuts slaughtered by the traditional Halal method are presented in Table 1. The total amount of zinc from 3 beef cuts was shown to be significantly different $(P<0.05)$. SET had the lowest zinc content $(19.54 \mathrm{mg} / \mathrm{kg})(P<0.05)$ when compared to LNG $(32.01 \mathrm{mg} / \mathrm{kg}) \mathrm{and}$ VAL (30.99 mg/kg) (Table 1). The results looked similar to previous reports in which zinc content was influenced by breed, anatomical location, and physiological activity. According to the USDA database, the level of zinc ranged between 34 and $100 \mathrm{mg} / \mathrm{kg}$ of raw meat [18]. Lombardi-Boccia et al. [19] reported that zinc content in 5 different meat cuts purchased in an Italian market ranged between 39.4 and $47.9 \mathrm{mg} / \mathrm{kg}$ wet meat. Thus, zinc content in 3 beef cuts slaughtered by the traditional Halal method was anatomically location-dependent.

The distribution of iron in muscle differed from zinc. The highest iron content was found in LNG $(15.93 \mathrm{mg} / \mathrm{kg})(P<0.05)$ when compared to SET $(12.12 \mathrm{mg} / \mathrm{kg})$ and VAL $(12.94 \mathrm{mg} / \mathrm{kg})($ Table 1). There was no significant difference in iron content between SET and VAL $(P>0.05)$. Theoretically, the iron content in beef is influenced by anatomical location, physiological activity, breed, sex, and nutrition plan. Previous research also found that breed was one of the factors influencing the total iron content. Iron content can be found at about 34 - 45 and $30-38 \mathrm{mg} / \mathrm{kg}$ wet meat in the Hereford breed and Braford breed, respectively [11]. Thus, it can be suggested that different iron content in 3 beef cuts was mainly due to anatomical location and physical activity.

\section{Myoglobin content and proportion of myoglobin forms}

Total myoglobin in 3 beef cuts slaughtered by the traditional Halal method are presented in Table 1. VAL showed higher myoglobin content $(2.67 \mathrm{mg} / \mathrm{g})$ than LNG $(2.54 \mathrm{mg} / \mathrm{g})$ and SET $(1.41 \mathrm{mg} / \mathrm{g})$, respectively $(P<0.05)$. Logically, the location of VAL is in the hindquarter of beef, in which it moves actively, compared to SET and LNG. It has been reported that the myoglobin content in L. lumborum was $4.36 \mathrm{mg} / \mathrm{g}[20]$.

Meat color, as one of important sensory properties of beef, can be influenced by myoglobin redox. The proportions of myoglobin forms in 3 beef cuts at $24 \mathrm{~h}$ post-mortem are depicted in Table 1 . In all cuts, deoxymyoglobin was the most predominant (55.67 - 59.89\%), followed by oxymyoglobin (30.51 $31.96 \%)$ and metmyoglobin $(9.60-12.37 \%)$. Thus, the beef cuts tended to have a dark purple-red color. SET had a lower proportion of deoxymyoglobin than LNG and VAL $(P<0.05)$. The proportion of oxymyoglobin was found to be highest in SET $(P<0.05)$. However, only $31 \%$ of oxymyoglobin was observed in all beef cuts at $24 \mathrm{~h}$ post-mortem. The results suggested that only a small amount of myoglobin was oxygenated during post slaughter, with a high $\mathrm{pH}$ value which made mitochondria outcompete for oxygen consumption compared to myoglobin. Therefore, under that condition, deoxymyoglobin or dark cutting meat would be predominantly formed in 3 beef cuts. For the metmyoglobin form, SET had a higher metmyoglobin proportion than VAL and LNG, respectively. However, comprehensively, all of the 3 beef cuts had a low metmyoglobin proportion. This happened 
http://wjst.wu.ac.th

because myoglobin was still in a reduced state (deoxymyoglobin and oxymyoglobin) at $24 \mathrm{~h}$ post slaughter. Moreover, scientifically, fresh meat still has a high content of metmyoglobin reducing activity (MRA), which can reduce ferric-metmyoglobin back to its ferrous counterpart [21]. So, the proportion of metmyoglobin in all 3 beef cuts was lower than the deoxy and oxy forms.

\section{Muscle pH}

The initial $\mathrm{pH}$ post slaughter $(3 \mathrm{~h})$ and the $\mathrm{pH}$ at $24 \mathrm{~h}$ post-mortem of 3 beef cuts slaughtered by the traditional Halal method are shown in Table 2. The $\mathrm{pH}_{(3 \mathrm{~h})}$ of SET (6.83) and VAL (6.93) was higher than LNG (6.26) $(P<0.05)$. It could be defined that all 3 beef cuts were collected from animals which underwent stress during the pre-slaughter and slaughtering process. Normally, as long as there is adequate glycogen present at slaughter, the $\mathrm{pH}$ of cattle will fall to within the normal range of $5.4-5.7$, but insufficient glycogen content in meat may lead to a sharp rise of $\mathrm{pH}$ [22]. Aghwan et al. [1] emphasized that inhumane handling of animals has been strongly correlated with psychological stress on animals before the slaughtering process. Additionally, the effect of stress on animals during pre-slaughter handling can raise the risk of loss of glycogen and increase ultimate $\mathrm{pH}$ post slaughter. Some researchers also stated that poor practice of animal handling from farm to slaughterhouse can cause stress on animals and contribute to the depletion of glycogen, as well as affect the quality of carcasses and meat postmortem [23]. Onenc and Kaya [24] reported that beef cattle being slaughtered without a pre-stunning method had a lower post slaughter $\mathrm{pH}_{(15 \mathrm{~h})}(\mathrm{pH}$ 6.50) compared to electrical stunning $(\mathrm{pH} 6.59)$ and percussive stunning ( $\mathrm{pH}$ 6.77), respectively. From 3 of those slaughtering methods, percussive stunning resulted in the highest glycogen content $(11.25 \mathrm{mM})$ compared to electrical stunning $(10.12 \mathrm{mM})$ and non-stunning $(8.84 \mathrm{mM})$ [24]. Nevertheless, the glycogen content has been strongly interlinked with the ultimate $\mathrm{pH}\left(\mathrm{pH}_{\mathrm{u}}\right)$ or $24 \mathrm{~h}$ post-mortem. Onenc and Kaya [24] also revealed that beef cattle handled, slaughtered, and processed without stunning had the highest $\mathrm{pH}_{\mathrm{u}}$ of 5.99 compared to percussive stunning $\left(\mathrm{pH}_{\mathrm{u}}\right.$ 5.75) and electrical stunning $\mathrm{pH}_{\mathrm{u}}$ 5.96). Our findings demonstrated that VAL had the highest $\mathrm{pH}_{\mathrm{u}}$ of $6.4(P<0.05)$ compared to SET and LNG $\left(\mathrm{pH}_{\mathrm{u}}\right.$ 5.8). VAL moved actively (kicking) during handling (overthrow/bring down) and the slaughtering process compared to other parts (SET and LNG). Therefore, it is believed that the amount of glycogen in VAL depleted faster than the others and may lead to high $\mathrm{pH}_{\mathrm{u}}$ post slaughter $(24 \mathrm{~h})$. Poor practice in animal handling is a trigger for releasing stress hormones into the blood (ACTH), followed by high concentration of cortisol hormone in the blood to increase the glycolysis process in the animal body [3,25]. During stressful conditions, the attitudes and behaviors of animals change dramatically, in which they become aggressive, reverse, vocalize, and have high movement, which contribute to a decrease in glycogen concentration, with an increase of $\mathrm{pH}_{\mathrm{u}}$, in carcasses and meat.

Table $2 \mathrm{pH}$, expressible drip, cooking loss, and hardness of 3 beef cuts, Semitendinosus, Longissimus dorsi, and Vastus lateralis, slaughtered by the traditional Halal method.

\begin{tabular}{lccc}
\hline \multicolumn{1}{c}{ Attributes } & Semitendinosus & Longissimus dorsi & Vastus lateralis \\
\hline $\mathrm{pH}_{(3 \mathrm{~h})}$ & $6.83 \pm 0.57^{\mathrm{b}}$ & $6.26 \pm 0.57^{\mathrm{a}}$ & $6.93 \pm 0.20^{\mathrm{b}}$ \\
$\mathrm{pH}_{(24} \mathrm{h}^{\mathrm{b}}$ & $5.83 \pm 0.57^{\mathrm{a}}$ & $5.83 \pm 0.20^{\mathrm{a}}$ & $6.40 \pm 0.20^{\mathrm{b}}$ \\
Expressible drip $_{(3 \mathrm{~h})}(\%)$ & $8.03 \pm 1.91^{\mathrm{a}}$ & $9.74 \pm 3.72^{\mathrm{a}}$ & $7.45 \pm 3.51^{\mathrm{a}}$ \\
Expressible drip $_{(24 \mathrm{~h})}(\%)$ & $16.57 \pm 4.35^{\mathrm{a}}$ & $17.62 \pm 1.40^{\mathrm{a}}$ & $15.50 \pm 1.75^{\mathrm{a}}$ \\
Cooking loss $_{(3 \mathrm{~h})}(\%)$ & $11.50 \pm 5.91^{\mathrm{a}}$ & $12.70 \pm 2.28^{\mathrm{a}}$ & $8.68 \pm 1.62^{\mathrm{a}}$ \\
Cooking loss $_{(24 \mathrm{~h})}(\%)$ & $16.64 \pm 1.15^{\mathrm{a}}$ & $17.90 \pm 1.52^{\mathrm{a}}$ & $15.89 \pm 0.67^{\mathrm{a}}$ \\
Hardness $_{(3 \mathrm{~h})}(\mathrm{N})$ & $10.24 \pm 4.09^{\mathrm{b}}$ & $7.37 \pm 3.67^{\mathrm{a}}$ & $10.45 \pm 3.98^{\mathrm{b}}$ \\
Hardness $_{(24 \mathrm{~h})}(\mathrm{N})$ & $9.45 \pm 2.59^{\mathrm{b}}$ & $7.35 \pm 1.57^{\mathrm{a}}$ & $9.50 \pm 2.59^{\mathrm{b}}$ \\
\hline
\end{tabular}

Values are given as mean \pm standard deviation from triplicate determinations.

Different letters in the same row indicate significant differences $(P<0.05)$. 


\section{Expressible drip}

The expressible drips of 3 beef cuts at $3 \mathrm{~h}$ post slaughter were less than $10 \%$ (Table 2). VAL tended to have the lowest expressible drip (7.45\%), followed by SET (8.03\%) and LNG (9.74 \%), respectively. From the results, VAL demonstrated the highest ability to retain water compared to the others because it had higher $\mathrm{pH}_{(3 \mathrm{~h})}$. The highest expressible drip in LNG may relate to the lowest $\mathrm{pH}_{(3 \mathrm{~h})}$ value, which was the closest to the isoelectic point (pI) of myosin (pI 5.4) [26]. With increasing post slaughter period (24 $\mathrm{h})$, the expressible drips of all cuts doubly increased $(P<0.05)$. This was in accordance with the decrease in $\mathrm{pH}$ of all cuts. Theoretically, drip loss can be influenced by $\mathrm{pH}$. It is accelerated by the decline of $\mathrm{pH}$ to the $\mathrm{pI}$. The lowest water holding capacity can be observed when $\mathrm{pH}_{\mathrm{u}}$ is equal or close to $\mathrm{pI}$. When the $\mathrm{pH}$ attains the $\mathrm{pI}$ of the major muscle protein, myosin (pI 5.4), the net charge of protein is zero, meaning that the numbers of positive and negative charges on the proteins are essentially equal [26].

Additionally, changes of drip loss or purge of water may also connect with the calpain system during the post-mortem period. Since proteolysis in meat occurs gradually over time, calpain has a great role in regulating proteolysis of muscle protein during the post-mortem period [26]. Increasing hydrophobicity and aggregation of the enzyme can occur because of conformational changes by alteration of $\mathrm{pH}[3,26]$. Likewise, changes in $\mathrm{pH}$ may alter the conformation of substrate proteins and render them less susceptible to cleavage by $\mu$-calpain [26]. Proteolysis of key muscle proteins, including desmin, vinculin, and talin, minimizes the loss of water-holding capacity caused by lateral shrinkage of myofibrils in post-mortem muscle [26]. These proteins have been shown to be degraded as early as $45 \mathrm{~min}$ to $6 \mathrm{hr}$ post-mortem in some muscles. Degradation of these proteins at such an early time post-mortem would certainly allow water that is expelled from the intra myofibrillar spaces to remain in the cell for a longer period of time [26]. Therefore, purge accumulation in all 3 beef cuts increased gradually over $24 \mathrm{~h}$ due to a reduction of $\mathrm{pH}_{\mathrm{u}}$. However, drip loss of LNG (17.62\%) was higher than SET (16.57 \%), even though they had the same $\mathrm{pH}_{(24 \mathrm{~h})}$ value. This was probably due to the differences of anatomical location, activity, and size of structure fiber in those cuts.

\section{Cooking loss}

Table 2 presents the cooking loss value in 3 beef cuts processed from the traditional Halal slaughtering method. At $3 \mathrm{~h}$ post-slaughter, VAL tended to show the lowest cooking loss $(8.68 \%)$, followed by SET $(11.50 \%)$ and LNG $(12.70 \%)$. With increasing post-mortem period up to $24 \mathrm{~h}$, the cooking loss in all cuts increased significantly $(P<0.05)$. The expressible drip at $24 \mathrm{~h}$ also followed the same order at $3 \mathrm{~h}$, as VAL $(15.89 \%)<\operatorname{SET}(16.64 \%)<\mathrm{LNG}(17.90 \%)$, respectively. The results were in agreement with the expressible drip formation in those cuts which occur in the same trend during both $3 \mathrm{~h}$ and $24 \mathrm{~h}$ post-slaughters. Purging of water during cooking is related to changes in the meat protein structure caused by increasing temperature [27]. Protein denaturation occurs and becomes insoluble between 50 and $90{ }^{\circ} \mathrm{C}$, in which the temperature can be triggered from collagen and gives an exerting pressure on myofibrils. Thus, water runs out of the matrix [27]. Degradation and denaturation of $\alpha$-actinin and myosin usually happen at low cooking temperatures, 50 to $58{ }^{\circ} \mathrm{C}$, and may lead to purge accumulation in beef [27]. Li et al. [28] stated that the degradation of proteins does not only affect meat tenderness, but also influences purging of water during ageing and cooking in beef. Based on the results, VAL had the lowest cooking loss, because VAL had the highest $\mathrm{pH}(24 \mathrm{~h})$. Additionally, there was an intermediate $\mathrm{pH}_{\mathrm{u}}(\mathrm{pH} 5.8$ - 6.2) related to limited degradation of desmin and troponin-T, which may explain why meat with high $\mathrm{pH}_{\mathrm{u}}$ had a better water holding capacity [28].

\section{Hardness}

Tenderness is one of the parameters determining consumer-eating satisfaction $[17,29]$. The hardness of 3 beef cuts slaughtered by the traditional Halal process at $3 \mathrm{~h}$ and $24 \mathrm{~h}$ post-slaughters are shown in Table 2. No changes in hardness of all beef cuts at $3 \mathrm{~h}$ and $24 \mathrm{~h}$ post-mortem were noticeable $(P>0.05)$. In both time periods, LNG had lower hardness than SET and VAL $(P<0.05)$. Differences of tenderness in 3 beef cuts are associated with muscle types and the ultimate $\mathrm{pH}$ of meat. The ultimate $\mathrm{pH}$ value can be influenced by ante-mortem stress and suffering during the slaughtering process. Beef cut with high ultimate $\mathrm{pH}$ is strongly related to high value of hardness. From the results, $\mathrm{LNG}$ had the lowest $\mathrm{pH}_{\mathrm{u}}(5.83)$ 
http://wjst.wu.ac.th

and was related to the lowest hardness value $(7.35 \mathrm{~N})$. Although SET had an equal $\mathrm{pH}_{\mathrm{u}}$ with $\mathrm{LNG}$, the former had a greater hardness value than the latter. The phenomena happened due to the type of muscle, anatomical location, and physiology activity. In addition, the length of sarcomere also plays an important role in beef tenderness [30]. It can be clearly seen that meat with greater expressible drip and cooking loss showed lower hardness value.

\section{Color}

The colors of 3 beef cuts at $3 \mathrm{~h}$ and $24 \mathrm{~h}$ post-mortem are presented in Table 3. For lightness $\left(\mathrm{L}^{*}\right)$ and yellowness $\left(\mathrm{b}^{*}\right)$, at $3 \mathrm{~h}$ post slaughter, SET had higher $\mathrm{L}^{*}$ and $\mathrm{b}^{*}$ values than VAL and LNG, respectively $(P<0.05)$. For redness $\left(\mathrm{a}^{*}\right)$, the highest value was also found in SET $(P<0.05)$, and no differences in $\mathrm{a}^{*}$ between LNG and VAL were noticeable $(P>0.05)$. A high value of $\mathrm{L}^{*}$ and a low value of $\mathrm{a}^{*}$ during $3 \mathrm{~h}$ post-slaughter indicated that all beef cuts underwent deoxygenation due to high $\mathrm{pH}_{(3 \mathrm{~h})}$ value (Table 2). These findings suggested that mitochondrial function may play a role in dark cutting beef $[20]$.

Table 3 Color of 3 beef cuts, Semitendinosus, Longissimus dorsi, and Vastus lateralis, slaughtered by the traditional Halal method.

\begin{tabular}{cccc}
\hline Color & Semitendinosus & Longissimus dorsi & Vastus lateralis \\
\hline Color & & & \\
$\left.\mathrm{L}^{*}{ }^{*} \mathrm{~h}\right)$ & $27.64 \pm 0.73^{\mathrm{c}}$ & $24.11 \pm 1.94^{\mathrm{a}}$ & $26.10 \pm 1.49^{\mathrm{b}}$ \\
$\mathrm{a}^{*}$ & $7.07 \pm 1.24^{\mathrm{b}}$ & $5.74 \pm 0.96^{\mathrm{a}}$ & $5.66 \pm 0.84^{\mathrm{a}}$ \\
$\mathrm{b}^{*}$ & $6.63 \pm 0.73^{\mathrm{c}}$ & $3.73 \pm 0.69^{\mathrm{a}}$ & $5.26 \pm 0.78^{\mathrm{b}}$ \\
Color $_{(24 \mathrm{~h})}$ & & \\
$\mathrm{L}^{*}$ & $25.50 \pm 1.34^{\mathrm{b}}$ & $24.11 \pm 1.36^{\mathrm{a}}$ & $27.13 \pm 1.67^{\mathrm{c}}$ \\
$\mathrm{a}^{*}$ & $10.29 \pm 1.24^{\mathrm{a}}$ & $9.50 \pm 0.96^{\mathrm{a}}$ & $10.90 \pm 0.84^{\mathrm{a}}$ \\
$\mathrm{b}^{*}$ & $11.66 \pm 0.73^{\mathrm{b}}$ & $9.21 \pm 0.69^{\mathrm{a}}$ & $9.10 \pm 0.78^{\mathrm{a}}$ \\
\hline
\end{tabular}

Values are given as mean \pm standard deviation from triplicate determinations.

Different letters in the same row indicate significant differences $(P<0.05)$.

After $24 \mathrm{~h}$ post-mortem, changes in $\mathrm{L}^{*}, \mathrm{a}^{*}$ and $\mathrm{b}^{*}$ values tended to show the same trend. No changes, or only a small decrease, in $\mathrm{L}^{*}$ values, in cases of LNG and VAL or SET, were found, whereas $\mathrm{a}^{*}$ and $\mathrm{b}^{*}$ values of all cuts markedly increased $(P<0.05)$. The results suggested that all cuts tended to be darker with increasing post-slaughter period. The highest $b^{*}$ value with the highest metmyoglobin proportion at $24 \mathrm{~h}$ was found in SET (Table 1), suggesting this was the darkest cut. Dark cutting beef was mostly due to animal stress during pre-slaughter and the exsanguination process. Physical distress in animals may lead to the depletion of glycogen in the muscles, resulting in high $\mathrm{pH}_{\mathrm{u}}$ [14]. Generally, during post-mortem and storage for $24 \mathrm{~h}$, the $\mathrm{pH}$ of beef will decrease gradually toward $\mathrm{pH}_{\mathrm{u}}$ of 5.5 - 5.7. However, when $\mathrm{pH}_{\mathrm{u}}$ exceeds 5.7, darkening of meat will occur completely [21]. Based on the measurement of $\mathrm{pH}_{(24 \mathrm{~h})}$ (Table 2), 3 beef cuts had $\mathrm{pH}$ values greater than 5.7. Therefore, VAL can be categorized as mildly dark cutting beef. However, SET and LNG at $24 \mathrm{~h}$ became redder than at $3 \mathrm{~h}$. This was probably due to a gradual decrease in oxygen consumption by mitochondria [31].

\section{Conclusions}

The traditional Halal slaughter in Thasala district followed the Holy Qur'an or Islamic law. However, inappropriate practice in animal handling and the slaughtering process risked the reduction of quality of beef through physiological stress on the animal. From the results, there was a relation between pre-slaughter handling, the slaughtering process, and muscle location with the chemical composition and 
http://wjst.wu.ac.th

physicochemical properties of Thai native beef. Animal stress seemed to be the most important factor influencing the overall quality of Thai native beef prepared by the traditional Halal method. An experiment regarding the effect of traditional Halal and non-Halal slaughtering methods on beef quality should be comparatively run in the future.

\section{Acknowledgements}

This work was supported by the Walailak University Fund (Contract No. 06/2561) and East Kalimantan Province, Indonesia.

\section{References}

[1] ZA Aghwan, AU Bello, AA Abubakar, JC Imlan and AQ Sazili. Efficient halal bleeding, animal handling, and welfare: A holistic approach for meat quality. Meat Sci. 2016; 121, 420-8.

[2] TL Desimone, RA Acheson, DR Woerner, TE Engle, LW Douglass and KE Belk. Nutrient analysis of the beef alternative merchandising cuts. Meat Sci. 2013; 93, 733-45.

[3] RA Lawrie and DA Ledward. Lawrie's Meat Science. Woodhead Publishing, Cambridge, 2006, p. 279-305.

[4] M Oh, E Kim, B Jeon, Y Tang, MS Kim, H Seong and S Moon. Chemical compositions, free amino acid contents and antioxidant activities of Hanwoo (Bos taurus coreanae) beef by cut. Meat Sci. 2016; 119, 16-21.

[5] AOAC. Official Methods of Analysis. Association of Official Analytical Chemists, Washington, DC, 2000.

[6] A Ramos, MC Cabrera and A Saadoun. Bioaccessibility of $\mathrm{Se}, \mathrm{Cu}, \mathrm{Zn}, \mathrm{Mn}$ and Fe, and heme iron content in unaged and aged meat of Hereford and Braford steers fed pasture. Meat Sci. 2012; 91, 116-24.

[7] PD Warriss. The extraction of haem pigments from fresh meat. J. Food Technol. 1979; 14, 75-80.

[8] C Faustman and A Phillips. Measurement of Discoloration in Fresh Meat. In: SJ Schwartz (ed.). Current Protocols in Food Analytical Chemistry. John Wiley and Sons Inc, New York, 2001.

[9] J Tang, C Faustman and TA Hoagland. Krzywicki revisited: Equations for spectrophotometric determination of myoglobin redox forms in aqueous meat extracts. J. Food Sci. 2004; 69, 717-20.

[10] CS Ng. Measurement of Free and Expressible Drips. In. H Hasegawa. (ed.). Manual on Analytical Methods and Procedure for Fish and Fish Products Laboratory. Southeast Asian Fisheries Development Center, Singapore, 1987, p. B3.1-B3.8

[11] PP Purslow, S Oiseth, J Hughes and RD Warner. The structural basis of cooking loss in beef: Variations with temperature and ageing. Food Res. Intern. 2016; 89, 739-48.

[12] E Onega, FRD Huidobro, E Miguel and B Bla. A comparison between two methods (WarnerBratzler and texture profile analysis ) for testing either raw meat or cooked meat. Meat Sci. 2005; 69, 527-36.

[13] RGD Steel and JH Torrie. Principle and Procedure of Statistics; a Biometrical Approach. MacGraw-Hill, New York, 1980.

[14] MM Farouk, KM Pufpaff and M Amir. Industrial halal meat production and animal welfare: A review. Meat Sci. 2016; 120, 60-70.

[15] NG Gregory, M von Wenzlawowicz, RM Alam, HM Anil, T Yeşildere and A Silva-Fletcher. False aneurysms in carotid arteries of cattle and water buffalo during shechita and halal slaughter. Meat Sci. 2008; 79, 285-8.

[16] SB Pflanzer and PE de Felício. Moisture and fat content, marbling level and color of boneless rib cut from Nellore steers varying in maturity and fatness. Meat Sci. 2011; 87, 7-11.

[17] CE Realini, SK Duckett, GW Brito, MD Rizza and DD Mattos. Effect of pasture vs. concentrate feeding with or without antioxidants on carcass characteristics, fatty acid composition, and quality of Uruguayan beef. Meat Sci. 2004; 66, 567-77.

[18] MC Cabrera, A Ramos, A Saadoun and G Brito. Selenium, copper, zinc, iron and manganese 
http://wjst.wu.ac.th

content of seven meat cuts from Hereford and Braford steers fed pasture in Uruguay. Meat Sci. $2010 ; \mathbf{8 4}, 518-28$.

[19] G Lombardi-Boccia, S Lanzi and A Aguzzi. Aspects of meat quality: Trace elements and B vitamins in raw and cooked meats. J. Food Comp. Anal. 2005; 18, 39-46.

[20] RO Mckeith, DA King, AL Grayson, SD Shackelford, KB Gehring, JW Savell and TL Wheeler. Mitochondrial abundance and efficiency contribute to lean color of dark cutting beef. Meat Sci. 2016; 116, 165-73.

[21] RAMancini and R Ramanathan. Effects of postmortem storage time on color and mitochondria in beef. Meat Sci. 2014; 98, 65-70.

[22] S Frimpong, G Gebresenbet, E Bobobee, ED Aklaku and IHamdu. Effect of transportation and preslaughter handling on welfare and meat quality of cattle: Case study of Kumasi abattoir, Ghana. Vet. Sci. 2014; 21, 174-91.

[23] J Holdstock, JL Aalhus, BA Uttaro, O López-Campos, IL Larsen and HL Bruce. The impact of ultimate $\mathrm{pH}$ on muscle characteristics and sensory attributes of the longissimus thoracis within the dark cutting (Canada B4) beef carcass grade. Meat Sci. 2014; 98, 842-9.

[24] A Onenc and A Kaya. The effects of electrical stunning and percussive captive bolt stunning on meat quality of cattle processed by Turkish slaughter procedures. Meat Sci. 2004; 66, 809-15.

[25] TJ Gibson, N Dadios and NG Gregory. Effect of neck cut position on time to collapse in halal slaughtered cattle without stunning. Meat Sci. 2015; 110, 310-4.

[26] E Huff-Lonergan and SM Lonergan. Mechanisms of water-holding capacity of meat: The role of postmortem biochemical and structural changes. Meat Sci. 2005; 71, 194-204.

[27] S Oillic, E Lemoine, J Gros and A Kondjoyan. Kinetic analysis of cooking losses from beef and other animal muscles heated in a water bath: Effect of sample dimensions and prior freezing and ageing. Meat Sci. 2011; 88, 338-46.

[28] P Li, T Wang, Y Mao, Y Zhang, L Niu, R Liang X and Luo. Effect of ultimate pH on postmortem myofibrillar protein degradation and meat quality characteristics of Chinese yellow crossbreed cattle. Sci. World J. 2014; 2014, 174253.

[29] JM Hughes, SK Oiseth, PP Purslow and RD Warner. A structural approach to understanding the interactions between colour, water-holding capacity and tenderness. Meat Sci. 2014; 98, 520-32.

[30] S Pen, YH Brad, G Luc and OA Young. Effect of pre rigor stretching on beef tenderness development. Meat Sci. 2012; 92, 681-6.

[31] J Tang, C Faustman, TA Hoagland, RA Mancini, M Seyfert and MC Hunt. Postmortem oxygen consumption by mitochondria and its effects on myoglobin form and stability. J. Agric. Food Chem. 2005; 53, 1223-30. 